\title{
Juri Vellan peilit
}

\author{
Eva Toulouze
}

Tunnetun metsänenetsirunoilijan, -poronhoitajan ja -aktivistin, Juri Vellan (1948-2013), tuotannosta löytyy useita omaelämäkerrallisia tekstejä. Kahteen niistä liittyy kuoleman läheisyys. Kuolemaan johtava sairaus ja sen myötä lähestyvä menehtyminen koettelivat ymmärrettävästi Vellaa ja johdattivat hänet perimmäisten kysymysten äärelle. Ne eivät loppujen lopuksi eroa toisistaan läntisissä kaupungeissa, Saharassa tai Siperian taigalla, vaikka vastaukset vaihtelevatkin. Esittelen ja kommentoin seuraavassa kahta Vellan omaelämäkerrallista suomennettua tekstiä ja avaan niiden suhdetta hänen elämäänsä ja toimintaansa (ks. myös Toulouze \& Niglas 2019).

Vellan ajatukset ovat länsisiperialaisen 40-vuotiaana metsänenetsiperinteen ja aatteidensa mukaiseen elämäntapaan palanneen alkuperäisasukkaan pohdintoja. Vuosina 1990-2013 Vella eli taigalla, Siperian soilla ja metsissä porojen kanssa viettäen sellaista modernia elämää, josta hän oli haaveillut lapsena. Hän loi elämäntapansa Venäjää ruokkivaa mutta Siperian luontoa ja sen elättämiä alkuperäiskansoja tuhoavaa öljyteollisuutta vastaan.

Ensimmäinen teksti on todellinen omaelämäkerta. 55-vuotias Vella mietiskeli ja kirjoitti leikkausten välisenä aikana. Kuten kaikilla teksteillä, omaelämäkerrallakin tuli olla tarkoitus, ja nyt Vellan päämääränä oli lähettää viesti. Hän tiesi olevansa sairas ja uskoi selviävänsä, mutta hän epäröi. Ensisijainen viesti on sijoitettu loppuun: "Ystävien keskellä tunnen itseni maailman onnellisimmaksi mieheksi."

Ystävät esiintyvät harvoin Vellan kirjoituksissa. Hän voi mainita sattumalta usein vanhempia ihmisiä tai sellaisia, jotka auttoivat arjessa, mutta Vella ei ilmaise erityistä läheisyyttä. Usein jonkun ihmisen tärkeys tuli ilmaistua välikäsien kautta ${ }^{1}$. Niinpä alla olevan tekstin loppua voi tulkita poikkeuksellisena tunnustuksena: Vella kertoo ystävilleen, että he ovat hänelle tärkeitä.

\section{Omaelämäkerta}

Varjoganin ja Novoaganskin välisellä tiellä on silta. Jos sillalta kulkee 400 metriä lounaaseen, saapuu vanhojen, sammaloituneiden mutta korkeiden kantojen luo paikkaan, jossa sijaitsi nenetsi Kyli Aivasedan (Vella) kotakylä. Synnyin siellä vuoden 1948 maaliskuussa. 
Miehensä, Kaly Vellan kuoleman jälkeen isoäitini Nengi jätti kodan ja porot ja palasi lastensa kanssa omien vanhempiensa leiriin. He asuivat lähellä Vatjogania, Settei-järven ja Hypitostan joen ympäristössä. Kolhoosionnea etsiessään he kulkivat, osin jalan, ja yhdessä Aivasedan suvun kanssa Varjoganin kylään Kansainvälisen Punastamisen aikoihin ja söivät siellä vuonna 1951 viimeisen vasansa.

Monien pohjoisten lasten tapaan kävin päiväkodin (muistan Stalinin kuoleman), kävin sisäoppilaitoksen (muistan Ensimmäisen Satelliitin ja Juri Gagarinin avaruuslennot).

Nuorena juttelin mieluiten vanhusten, Jeparkinin veljesten, Vasilin ja Antonin, ja Jefim Aipinin kanssa. Vanhemmitenkin olin aina vanhemman sukupolven varassa, Jusi Kulin, Aulin ja Oisjan, Andrei Kazamkinin. Mutta luonteeseeni vaikuttivat luullakseni eniten kaksi henkilöä, isäni äiti, isoäiti Nengi ja äitini isä, isoisä Hopli.

Työskennellessäni valtionmetsästäjänä osallistuin Gorkin Kirjallisuusinstituutin kirjekurssille ja puolustin diplomityötäni, ”Uutisia kotakylästä”, vuonna 1988 erinomaisin arvosanoin.

Tälläkin hetkellä toimin kahden asian parissa: paimennan poroja ja merkitsen muistiin perinnettä, kansani tämänpäiväisen kulttuuritason peiliä - jotta kuka tahansa voisi sillä peilailla.

Vuonna 2000 minut hyväksyttiin Venäjän kirjailijaliittoon.

Elän Agan-joen suistossa porojen kanssa. Virallisesti asun Varjoganissa. Vuosien 1978-79 aikana meidät ja maamme siirrettiin Surgutin piiristä Nižnevartovskin piiriin.

Elämässäni on sattunut kaikenlaista: olen julkaissut viisi kirjaa, perustanut kaksi museota ja kaksi koulua, yhden kyläneuvoston; muutaman vuoden olin metsästyskolhoosin paras metsästäjä. Aikoinaan ilmoittauduin vapaaehtoiseksi Vietnamiin, mutta lattajalkaisuuden vuoksi palvelin rakennustöissä; vastustan kategorisesti Tšetšenian sotaa, mille on omistettu kirja "Joutsenten metsästys". LUKoilin työntekijät ovat neljästi tehneet minusta valheellisen rikosilmoituksen: olen voittanut kolme ja neljäs juttu odottaa käsittelyä Eurooppaoikeudessa. Vieläkään en ole selvinnyt vuoden 1992 tulipalon aiheuttamasta köyhyydestä: $90 \%$ vaatteistani olen saanut lahjaksi ystäviltäni ja asuntoni kalusteista puolet on entisestä koulustani. Siltikin olen saamassa valmiiksi uudistetun version tulipalossa tuhoutuneesta "Järvituuli"-käsikirjoituksesta, kirjoittanut nenetsikoululaisille kirjasen "Kertomus rakkaudesta", jolle etsin sponsoreita. Valmistelen paikannimisanakirjaa, jonka työnimi on "Agan ja sen sivujoet".

Tänään Kohtalo koettelee minua uusin tavoin: olen maannut eri sairaaloissa lokakuusta alkaen, minulle on tehnyt kolme leikkausta ja vaikeuksista huolimatta lienen parantumassa. Ja ilman ystävien tukea...

Ystävien keskellä tunnen itseni maailman onnellisimmaksi mieheksi.

Kirurginen osasto

Nižnevartovsk

(Vella 2008: 154-155.)

Teksti on täynnä huomionarvoisia yksityiskohtia. Vella on valinnut merkityksellisimmät kokemukset, sellaiset joiden myötä välittyy viesti. Yksi viesteistä on, että häntä ei voida henkilönä erottaa tilasta; paikat määrittelevät hänen elämäänsä. Hänen syntymäpaikkansa ja perheensä liike muodostavat hyvin konkreettisen tilan etäisyyksineen ja jokineen (jotka ovat Siperiassa tärkeimpiä tilan nimittäjiä). Kirjoittaessaan elämästään ja sen suhteesta tilaan 
Vella ei jätä mainitsematta hallinnollisia muutoksia, joiden vuoksi "hänen" alueensa siirtyi piirikunnasta toiseen, minkä vuoksi alue eriytyi luonnonympäristöstään. Muutoksessa metsänenetsiä ja hantin Surgutin murretta puhuvan, Aganin jokialueella elävän väestön alueesta tuli osa Nižnevartovskin piiriä, jonka keskiössä on Obin sivujoen Vahin jokialue. Siellä puhutaan täysin toista hantin murretta. Äärimmäisen lakoniseen ja yksinkertaiseen muotoon verhoutuu useita henkisiä vaurioita, joita ymmärtääkseen pitäisi tuntea taustoja, kuten seuraavassa asuinpaikkaa kuvaavassa lainauksessa: "Elän Agan-joen suistossa porojen kanssa. Virallisesti asun Varjoganissa. Vuosien 1978-79 aikana meidät ja maamme siirrettiin Surgutin piiristä Nižnevartovskin piiriin". Koko teksti on samalla tavalla tiheänään paikallisesti tärkeitä käsitteitä. Tapahtuma on niin merkityksellinen, että sille on annettu tarkka vuosiluku.

Yksinkertaisuus ja merkityksellisyys muistuttavat Vellan hyvän ystävän, hantiälymystöön kuuluvan Agrafena Pesikovan tapaa korostaa sitä, että hantien kulttuuri rakentuu salaisuuden varaan. Hän luonnehtii kulttuuria "avoimesti suljetuksi": kaikki tarpeelliset vihjeet ovat näkyvillä, mutta niiden tulkinta edellyttää kulttuurin syvällistä tuntemusta.

Ennen kuin siirryn Vellan elämään, haluaisin vielä kommentoida aikakehystä. Elämäkerrassa kronologia on luonnollisesti keskeinen, minkä vuoksi lukija odottaa päivämääriä. Syntymävuosi on ensimmäinen. Toinen on kiintoisampi: vuosi, jolloin vanhemmat söivät viimeisen poronsa ennen muuttamistaan Varjoganiin. Tässäkin kohtaa viesti on poikkeuksellinen tiivis: "söivät siellä vuonna 1951 viimeisen vasansa". Tietystikään Vella ei kirjoita ruoasta. Hänen viestinsä on, että he onnistuivat pitämään perheen poroelon kollektivisaatiosta huolimatta vuoteen 1951 asti. Teksti kuvaa lyhytsanaisesti, miten kovia Stalinin ajan lopun rajoitukset olivat. Nälkä toimi pääasiallisena pakkokeinona, sillä sodan aikana ja sen jälkeisinä vuosina metsästys- ja kalasaaliit tuli antaa valtiolle. Vella kertoi usein rakastavansa kiiskeä, sillä hän kasvoi syömällä tätä pientä kalaa, joka oli ainoa saalis, jota kalastajien ei tarvinnut antaa valtiolle. Jatkuvan nälän vuoksi perhe ei voinut uudistaa poroeloa, mikä merkitsi luopumista alkuperäiskansaidentiteettiä keskeisesti ilmentävästä elämäntavasta. Tämä suhteellisen mitätön lause sisältää päiväyksen, sillä se on Vellan elämän käännekohta. Hän oli tuolloin kolmevuotias, mikä tarkoitti, että hänen tuli kasvaa ilman poroja.

Vellan elämään liittyvien päivämäärien lisäksi voidaan mainita selkeitä historiallisia konteksteja, jotka hän on nimennyt kiinnostavalla tavalla: Kansainvälinen Punastaminen, Kolhoosionnen etsintä, Stalinin kuolema ja Ensimmäinen Satelliitti. Toisin sanottuna vuodet 1917-1918, 1930, 1953 ja 1961. Ensimmäinen nimi on kiinnostava: punastaminen on helppo ymmärtää, mutta miksi "kansainvälinen"? Viittaako Vella vuoden 1918 Unkarin ja Saksan neuvostotasavaltoihin? Vastaus löytyy ennemmin toisaalta, isoista alkukirjaimista, jotka elollistavat yleiskäsitteet ja muuntavat ne metaforisiksi. Samaa menetelmää ovat käyttäneet muutkin pohjoiset alkuperäiskansakirjailijat, esimerkiksi Jeremei Aipin. Keinon avulla abstraktit käsitteet elollistuvat toimijoiksi, tai ainakin mahdollisiksi toimijoiksi.

Viimeiseksi on vielä korostettava inhimillistä kehystä eli ihmisiä, jotka ovat olleet Vellalle tärkeitä. Hän ei sijoita itseään genealogioihin, vaan ihmisiä yhdistää heidän ikänsä: he ovat vanhempia, mutta kaikki eivät ole metsänenetsejä, sillä Jeparkin, Aipin ja Kazamkin ovat hantiklaanien nimiä. Vella ei siis liitä itseään etniseen yhteisöön, vaan eräänlaiseen alkuperäiskansojen "kattodynastiaan" (myös Niglas 2001).

Pohtikaamme vielä niitä tekijöitä, joihin Vella elämässään kiinnittää huomiota. Ensinnäkin koulutus, eli päiväkoti ja sisäoppilaitos ja tavallinen alkuperäisasukkaan elämä. Maksim Gorkin Kirjallisuusinstituutti esitetään täysin tavanomaisena. Sivumennen sanoen hän ei mainitse niitä suuria havaintoja, jotka luonnehtivat aikakautta. Sen sijaan Vella päivää opintojen 
loppumisen ja valmistumisen, minkä vuoksi näitä voi pitää hänen elämänsä tärkeinä hetkinä.

Toimistaan hän korostaa kahta, kenties yllättävää ulottuvuutta: "paimennan poroja ja merkitsen muistiin perinnettä’. Ensimmäinen on luonnollisesti perustavaa laatua oleva, sillä Vella kirjoitti tekstin toimiessaan poronhoitajana, jolloin hän oli pääasiallisesti tekemisissä poroelonsa kanssa päivittäin.

Toinen tekijä on yllättävämpi, vaikka onkin totta, että Vella tallensi 1980- ja 90-luvuilla perinnettä naapureiltaan, muun muassa aiemmin mainituilta miehiltä. Mutta vuonna 2003 he olivat kaikki poistuneet tuonilmaisiin. Heidän jälkeläisillään, hänen senaikaisilla naapureillaan, ei ollut enää perinnettä kerrottavaksi. Kun tallensin metsänenetsien folklorea yhdessä virolaisen kielitieteilijän, Kaur Mägin kanssa vuonna 2000, Vella ei osallistunut muutoin kuin erinomaisena informanttina. Kirjoittaessaan "merkitsen muistiin" Vella antaa silti ymmärtää, että sisältö ei ole lähtöisin hänestä itsestään: hän kirjaa toisten kertomaa. Edelleen hän lisää: "kansani tämänpäiväisen kulttuuritason peiliä - jotta kuka tahansa voisi sillä peilailla". Tämä viimeinen huomio on tärkeä. Ensinnäkin se tukee tulkintaa siitä, että kyseessä ovat Vellan kirjoitukset; toiseksi hän tekee niiden avulla nenetsien ja hantien kulttuurin saavutettavaksi mille tahansa yleisölle. Vella tekee täyskäännöksen ja paljastaa, minkälaisen aseman haluaa kirjoituksilleen antaa. Ne eivät edusta alkuperäisväestöön kuuluvan yksilön kirjoituksia, vaan ovat hänen edustamansa yhteisön peilikuva. Ajatuksessa välittyy toive siitä, että tekstit voisivat toimia suullisen ilmaisun tapaan, että hän voisi sulautua hahmoksi, joka koostuu monesta, esittää sitä ja antaa sille äänen, olla vox populi.

Kun tarkastellaan tapaa, jolla Vella arvioi kokemustensa ja saavutustensa eri puolia, huomaamme hänen valinneen vain merkittävimmät tapahtumat kappaleessa, jossa on useita luetteloita.

Ensimmäiseksi hän luettelee ja laskee luomuksensa: viisi kirjaa, kaksi museota, kaksi koulua ja yksi maaseutuneuvosto. Vella haluaa esittää itsensä eri yhteiskunnan alueiden kehittäjänä. Mutta mihin kirjoihin hän viittaa? Hän on todennäköisesti valmistelemassa kuudetta, jossa aikoi julkaista tämän Omaelämäkerran. Oikeastaan nämä viisi kirjaa ovat kaksi + kaksi + yksi. Ensimmäinen on kokoelma "Uutisia kotakylästä" (Vesti iz stoibištša), joka on hänen lopputyönsä Gorkin kirjallisuusinstituutissa. Ensimmäiseen, Sverdlovskissa vuonna 1991 julkaistuun painokseen piti tehdä joitakin pieniä toimittajan sanelemia muutoksia. Jotkut muutoksista liittyivät venäjään, jota Vella käytti tietoisesti hieman virheellisesti, koska ei ole eikä halunnut olla venäläinen runoilija. Tästä syystä hän julkaisi vuonna 1991 samannimisen kokoelman pienessä siperialaisessa Radužnin kunnassa. Kokoelma oli vaatimaton vihkonen, mutta tekstit on siinä julkaistu niin kuin Vella ne alkujaan kirjoitti, ilman ulkopuolisten sekaantumista. Kolmas kirja julkaistiin vuonna 1996 Surgutissa ja neljä vuotta myöhemmin toinen surgutilainen kustantaja teki siitä uusintapainoksen. Kokoelman nimi oli "Valkoisia huutoja: kirja iäisestä" (Belye kriki: kniga o veť̌nom).

Kirjailijana Vella ei ollut monisanainen. Yllämainituissa kirjoissa jotkut runot esiintyivät kahdesti. Mutta Vella on asettanut runot uuteen kontekstiin ja yhdistellyt niitä, ja siten on syntynyt uusia merkityksiä. Viidennessä kirjassaan, vuonna 2001 Hanty-Mansiskissa julkaistussa kokoelmassaan hän teki samoin. Teos oli myös ensimmäinen, muttei viimeinen, monikielinen julkaisu, jossa hänen tekstejään oli käännetty ranskaksi. Kokoelmaa ei ollut tarkoitus levittää laajalti Ranskassa. Sen sijaan tarkoituksena oli osoittaa siperialaisille kumppaneille, että häntä kuunnellaan maailmalla. Vella oli julkaissut nyt viisi kirjaa; hän tulisi julkaisemaan vielä useita tulevien vuosien aikana. 
Tekstissä mainitut kaksi museota ovat kaksi toisistaan täysin poikkeavaa kokonaisuutta: toinen on ulkoilmamuseo, jonka Vella perusti Varjoganiin, ja toinen oli olemassa vain hänen puheessaan - tai hänen elämässään metsässä, mitä hän kutsui "ekomuseoksi". Ei ole aivan selvää, mihin hän viittaa kahdella koululla. Silti yksi Vellan omaperäisimmistä aloitteista oli hänen kotakyläänsä perustama koulu, joka toimi eri tiloissa. On vaikea esittää, että hän olisi perustanut maaseutuneuvoston Aganiin, vaimonsa kotikylään, vaikka hän toimikin ensimmäisenä neuvoston alkuperäiskansajohtajana.

Luetteloiden jälkeen Vella kertoo kolmesta tapahtumasta elämässään. Ne kuvaavat hänen suhteitaan instituutioihin. Hän oli metsästyskolhoosin paras metsästäjä, halusi lähteä Vietnamiin, vastusti Tšetšenian sotaa. Näiden seikkojen avulla hän haluaa korostaa tiettyjä tärkeitä luonteenpiirteitään. Itse Vella arvosti eniten kriittistä ajatteluaan. Vaikka hän saikin tunnustusta, hän ei halunnut perustaa valintojaan Neuvostoliiton tai Venäjän harjoittamalle propagandalle, vaan omalle vakaumukselleen. Tšetšenian sotaa hän vastusti hyvin avoimesti ja suhtautui myös kriittisesti Venäjän hyökkäykseen Georgiaan vuonna 2008. Vella ei ollut vastustamisessaan systemaattinen, vaan hän korosti kriittisen ajattelun, itsenäisten pohdintojen ja johtopäätösten tekemisen merkitystä.

Vella ei vastustanut vain valtion toimia. Hänen elämänsä viimeisiä 15 vuotta luonnehtivat jatkuvat yhteenotot LUKoilin kanssa (ks. Niglas 2016). Hän tiivistää tapahtumat kertomalla yhtiön kanssa käydyistä oikeusjutuista. Lauseista voi päätellä, että sen lisäksi että LUKoil oli valloittanut Vellan maat laittomasti, yhtiö hyökkäsi toistuvasti häntä vastaan ja teki hänestä kaksinkertaisen uhrin. Juri ei antanut komennella itseään. Hän vastasi kanteisiin ja kääntyi jopa kansainvälisen oikeuden puoleen.

Vella palauttaa maan pinnalle ne, jotka haluaisivat rakentaa kuvaa puhtaasta kirjailijan sielusta. Vuoden 1992 tulipalo, joka tuhosi hänen talonsa, oli vakava menetys erityisesti koska samanaikaisesti koko kylän talous oli vaakalaudalla. Kolhoosi romahti ja sen mukana alkuperäisväestöä työllistänyt matkamuistopaja, jossa Vellan vaimokin työskenteli. Henkilökohtainen tapahtuma selittää köyhyyden, mutta tulipalon myötä Vella pystyy kääntymään kohti nykyhetkeä: miten tuhoutuneen käsikirjoituksen voisi saattaa entiselleen... kirjoittamalla, kirjoittamalla, kirjoittamalla... Vella päättää tekstin mainitsemalla paikannimisanakirjan (Reka Agan s pritokami), jonka työstämiseen kului kymmenen vuotta. Mutta ennen kuolemaansa hän oli saanut sen valmiiksi.

\section{Viimeinen monologi}

Ensimmäinen kysymys kuuluu: mikä ihminen on ja minkä vuoksi hän elää.

Lattea koulutehtävä; koulussa kirjoitettiin aineita tästä - tai en tiedä, kirjoitetaanko nykyään, mutta me kirjoitimme. Sinähän tiedät, että jos vastaisi kysymykseen selvästi, se olisi todella vaikeaa.

Katsoin opettajaa ja ymmärsin, että kysymys oli neuvostoliittolainen, johon osasimme vastata: istuttaakseen puun, kirjoittaakseen kirjan, jättääkseen jäljen - hyvän tietenkin.

Kysymys jää kuitenkin ihmisen sieluun ja mitä kauemmin elää, vanhemmaksi elää, sitä enemmän alkaa toistaa sitä, etsiä vastausta, mutta ei enää koetta tai ainetta varten, vaan lastenlapsia varten, lastenlastenlapsia varten. Heistä ei ehkä tarvitse kirjoittaa ainetta, vaikka ehkä pitäisi.

Mitä elämä on? Mikä ihminen on? Miksi ihmiselle on annettu elämä? Miksi hän syntyi tähän maailmaan? 
Auli kuoli. Kaksi päivää ennen kuolemaa menin hänen luokseen, hänen vuoteelleen, ja hän tiesi tekevänsä kuolemaa... Tukeakseni häntä ja hänen sieluaan sanoin: 'Tiedätkö, ihminen ei vain yksinkertaisesti häviä. Vaikka ruumis kuolee, hänen sielunsa säilyy ja jatkaa elämää.” Hän vastasi minulle: "Varmaankin niin, mutta jos ihmisen jälkeen tähän maahan ei jää yhtäkään kotaa, niin minkä vuoksi ylipäätään elin? Miksi kasvatin lapseni? Jos jälkeeni ei jää yhtäkään kotaa?"

Minä luulin tulleeni tukemaan hänen sieluaan, mutta näyttääkin siltä, että hän kuolemaa tehdessään koetti tukea minun sieluani.

Kotakyläni on tällä hetkellä tässä. Aiemmin tässä oli isoäitini kotakylä. Tarkalleen ottaen ei ihan tässä, vaan vähän matkan päässä, vähän etelämpänä - isäni äidin. Täällä Vatjoganilla syntyi äitini äiti. Elänkin nyt kahden isoäitini mailla.

Ennen isoäitiäni täällä, tästä kolmen kilometrin päässä oli Vankutja Vellan kotakylä. Ja kun miettii, kuka on elänyt kauempana: siellä, missä on viides työpaja, siellä on Yvy Tjatjai. Ja kun paikalla on kerran sellainen nimi, ihmisen nimi, siellä eli Yvy-niminen ihminen. Samoin Vatjoganin pyhä paikka, Kapitjain soho², on nimetty Kappin mukaan. Paikalla asui siis joskus Kappi. En tiedä, kenen sukulainen hän oli, mutta hänen nimensä on jäänyt paikannimistöön, eli hän elää edelleen. Kun olen merkinnyt muistiin paikannimistöä, olen jättänyt nimen hänelle. En tiedä hänen sukunimeään tai muitakaan nimiään; nenetseille hän oli vain Kappi, sananmukaisesti toissukuinen. Varmaankin hanti. Ja Yvi oli hänen tyttärensä. Yvistä tuli isoäitini täti, toisin sanottuna yksi isoäitini sukulaisista meni hänen kanssaan naimisiin.

Ja sitten täältä, viitisentoista kilometriä täältä, on isoäitini isän, Heši Aivasedan hauta. Ja siellä, mistä alkaa harju, se harju, jolla aloitetaan hakkuut, sinne on haudattu Jusi Koltšu, jonka nimen olen yrittänyt jättää lapsenlapselleni. Koska lapsenlapseni ei ole vain minun, vaan myös hänen, Jusi Koltšun, jälkeläinen.

11.9.1924 tämä Jusi Koltšu valittiin kansankokouksessa metsänenetsien vanhimmaksi. Siitä todistaa Raisa Pavlovna Mitusovan, valkokenraali Kutepovin siskon, muistiinpanot.

Näin tämä maa liittyy moniin nimiin. Nimien joukkoon jäänee minunkin nimeni. Vaimoni nimi, tyttäreni nimi. Miten ne kestävät aikaa, ehkä vuoden tai kaksi ja jos kauemmin, ei se haittaa. Se on vähän niin kuin muistomerkki. Mutta jos tänne ei jää yhtäkään kotaa, kuka tällaisia miettii, kuka muistelee?

Kuka kertoo lapsenlapsilleen, kuka täällä asui ja kuka mitäkin teki. Kuka tapaa huomenna virkamiehiä ja yrittää ottaa haltuunsa porolaitumet heidän mielivallaltaan, heidän rahanhimoltaan? Yrittää osoittaa, että tähän maahan kajoaminen ei ole ekologian kannalta mielekästä.

Vaikka periaatteessa heidän, metsätyömiesten, ekologien, pitäisi tulla luokseni ja sanoa: ”Älä kajoa tähän maahan! Älä vahingoita tätä maata!” Heille maksetaan siitä palkkaa. Mutta näyttää siltä, että minä, päinvastoin, teen tätä työtä.

Isoäiti, juodaanko teetä?

Ylläoleva teksti ei luonnollisestikaan ole oikea testamentti. Se on Olga Kornijenkon ${ }^{3}$ kameralle esitetty monologi kaksi kuukautta ennen Vellan kuolemaa, heti kemoterapiajakson jälkeen. Sitä ennen Vella oli osallistunut konferenssiin (jossa vietin viimeisen kerran aikaa hänen kanssaan), jonka aikana hänelle nousi kuume ja hän joutui muutamaksi päiväksi sairaalaan. Heti kotakylään palattuaan hän kertoi ajatuksistaan elokuvantekijälle, joka teki niistä kuoleman jälkeen elokuvan "Viimeinen monologi” (Kornijenko 2013). 
Filmi on tunteikas ja sitä on raskas katsoa. Vella tuntee kuoleman lähestyvän eikä keskeistä kysymystä oman elämän merkityksestä voi enää vältellä. Hän etsii vastausta ja löytää sen vanhempiaan kuunnellen - niin kuin Omaelämäkerrassakin. Kuolemaa tekevä naapuri, Auli Jusilla on vastaus: "jos ihmisen jälkeen tähän maahan ei jää yhtäkään kotaa, niin minkä vuoksi ylipäätään elin?” Kodan jättäminen jälkeensä tarkoittaa, että jättää maan asutuksi ja varmistaa elämän jatkuvuuden. Kyseessä ei ole vain biologinen elämä, vaan elämä niin kuin alkuperäisasukkaat sen ymmärtävät. Kota symboloi elämää. Jos kaikki elämä katoaa, oliko omalla elämällä mitään merkitystä? Kota on tässä symbolinen, sillä eivät Juri ja Auli eläneet enää kodissa. Ainoastaan vanha Oisja kieltäytyi lähtemästä omastaan. Kota viittaa alkuperäiskansan elämään vuorovaikutuksessa luonnon kanssa, arvokkaaseen ja vastuuntuntoiseen elämään. Jos se katoaa kuoltuamme, teimmekö oikein?

Vella kyynelehtii lähes taukoamatta monologin aikana. Hän kysyy, jääkö jotain hänen jälkeensä. Pohdinnassa on samaa tilallisuutta kuin omaelämäkerrassa, mutta nyt se tulee esiin eri paikoissa eläneiden ja haudattujen ihmisten nimissä. Säilyykö hänen nimensä? Jonkin aikaa, mutta miten pitkään?

Vella halusi tulla haudatuksi taigalle, jotta hänen nimensä olisi voitu kirjoittaa maisemaan niin kuin hänen esi-isiensäkin nimet. Kuoleman jälkeen omaiset eivät seuranneet hänen tahtoaan, vaan hautasivat hänet kylän hautausmaalle. Vaikuttaako se hänen nimensä esiintymiseen paikannimissä? Miten pitkään paikannimistö säilyttää paikallisväestön historiaa, kun kielet häviävät vähä vähältä?

Ahdistus jatkuu viimeisissä lauseissa. Tuleeko vastuullisia alkuperäiskansojen edustajia? Pystyvätkö lapsenlapset toimimaan huolehtien maastaan ja jatkamaan suojelua, jota viranomaiset eivät edellytyksistä huolimatta tee? Vella on äärimmäisen huolissaan ja huoleen on yhdyttävä.

Vella ei lähtenyt rauhassa, varmana perinnöstään. Hän oli kertonut huolistaan jo vuonna 2009 minulle ja Liivo Niglasille valittaessaan, että hänen kasvattamansa lapsenlapset käyttäytyivät kuin muutkin maailman teini-ikäiset. Yritin silloin palauttaa Vellaan optimismia muistuttamalla häntä siitä, millainen hän itse oli teini-ikäisenä. Haluaisin vastata samoin nyt, vaikka ymmärränkin hänen epäilyksensä. Vella rakensi aina utopiaansa tuonnemmas. Hänen vaikutustaan voi arvioida vasta muutaman sukupolven päästä.

Suomentanut Karina Lukin

\section{Viitteet}

1 Vellan kotakylässä kuulin monesti antropologi Stephan Dudeckista, jonka Vella tunsi koska Stephan oli, Vellan sanoin, "Berliinin yliopiston opiskelija". Vellalle hän oli suuri auktoriteetti. Hän toisteli: "Stephan sanoi, Stephanin mielestä, Stephan tietää, että... Mitähän Stephan ajattelisi...?" Stephanin mukaan Vella ei koskaan ilmaissut suoraan arvostustaan ja kritisoi häntä jatkuvasti. 
2 Kappimäki, suom. huom.

3 Olga Kornijenko (Bystrjakova) on venäläinen, Surgutissa asuva elokuvantekijä. Hän aloitti tekemään raportteja alueen alkuperäisväestöstä työskennellessään Surgutin televisiossa. Juri ystävystyi Kornijenkon kanssa, näki hänessä kykyjä ja pyysi häntä työryhmineen tulemaan luokseen Agan-joelle katsomaan, miten ihmiset elävät jokirannoilla ja millaisia vanhat kotapaikat ovat. Retken pohjalta syntyi elokuva (Kornijenko 1996) ja myöhemmin Kornijenko on tehnyt muitakin menestyneitä elokuvia alkuperäiskansoista. Hän oli loppuun asti läheinen Jurin ystävä ja on viime aikoina julkaissut essee- ja muistelmakokoelman, jossa Jurilla on merkittävä asema. (Kornijenko 2016: $152-158,172-206)$.

\section{Lähteet}

Kornijenko, Olga (1996), Putjem hozjaiki Agana. Surgutinform-TV.

Kornijenko, Olga (2013), Poslednyi monolog (film). Surgutinform.

Niglas, Liivo (2001), Yuri Vella's world. MP Doc \& F-Seitse.

Niglas, Liivo (2016), The Land of love. MP Doc \& F-Seitse.

Toulouze, Eva \& Niglas, Liivo (2019), Yuri Vella's fight for Survival in Western Siberia. Oil, Reindeer and Gods. Newcastle upon Tyne: Cambridge Scholars.

Vella, Juri (2008), Pogovori so mnoi: kniga dlja nenetskogo studenta i dlja togo, kto hotel by poslušat nenetskuju dušu. Hanti-Mansiisk: Poligrafist. 